\title{
IMPACT OF FEED ROLLERS ON PRODUCTIVITY AND FUEL CONSUMPTION
}

\author{
Agris Zimelis, Santa Kaleja, Gints Spalva, Andis Lazdins \\ Latvian State Forest Research Institute "Silava, Latvia \\ agris.zimelis@silava.lv, santa.kaleja@silava.lv, andis.lazdins@silava.lv
}

\begin{abstract}
The aim of the study was to evaluate the impact of the harvester head feed roller type on the fuel consumption and productivity during the spring season. This study compares feed rollers with moving metal plates on rubber shock absorbers (Moipu plate wheel rollers, hereinafter named - gentle feed rollers) and feed rollers with large round spikes (hereinafter named - conventional feed rollers). The study was conducted in Vidusdaugava forestry (forests managed by the Joint Stock Company Latvia State Forests). A total area of 18.69 ha or 19 felling sites were logged in the final felling with gentle feed rollers and 20.29 ha or 15 felling sites - with conventional feed rollers. Harvested spruce saw logs were delivered to Rettenmeier Baltic Timber Ltd, pine sawlogs to IKEA Industry Latvia Ltd and veneer logs to Latvijas Finieris Ltd. APonsse Ergo harvester manufactured in 2008 with a standard $\mathrm{H} 7$ felling head was used in the study. Logging tests were carried out in the spring and early summer, using standard logging work tasks with both feed roller types.According to the data from the harvester onboard computer the productivity was $27 \mathrm{~m}^{3} \cdot \mathrm{h}^{-1}$ using the gentle feed rollers and $33 \mathrm{~m}^{3} \cdot \mathrm{h}^{-1}$ using the conventional feed rollers. However, the comparison of productivity while processing the trees of the same diameter demonstrated slightly weaker performance with the gentle feed rollers. The difference is statistically significant if the tree diameter at the breast height is below $20 \mathrm{~cm}$. Further studies are necessary to investigate the productivity depending on the season and felling type. Fuel consumption using the gentle feed rollers was $18.02 \mathrm{l} \cdot \mathrm{h}^{-1}$ and using the conventional feed rollers it was $16.75 \mathrm{l} \cdot \mathrm{h}^{-1}$. Fuel consumption by the roller type has a significant impact on both mean values $\left(t_{\text {Stat }}=2.6>t_{\text {Crit }}=1.64\right)$ and data dispersion $\left(F=0.9>F_{\text {Crit }}=0.8\right)$.
\end{abstract}

Keywords: mechanized logging, productivity, feed rollers, fuel consumption.

\section{Introduction}

The use of a harvester felling head fitted with feed rollers in cut-to-length harvesting has always been associated with damages occurring during the log processing. It is connected with the operation principle and the structure of the feed rollers, described by Nilsson in his publication [1]. The force, which is exerted by the feed roller on the stem, is important. If the force is too small on the rollers, bumps are formed, if the pressure is too big, dents are formed in the wood. The damage caused by the feed rollers has been known since their invention in the $20^{\text {th }}$ century.

Over the period of time since harvesters were introduced in the production until about the year 2000 , there have been several studies on increasing of the work productivity and efficient use of time in logging operations. In some studies the advantages of rubber feed rollers over metal feed rollers have been mentioned. As one of the drawbacks of rubber feed rollers a significant decrease in work productivity has been mentioned, in spite of smaller damages caused by the rollers [2-4].

According to the studies implemented in Finland the Moipufeed rollers with adaptable plate produced the smallest damages $(3.7 \mathrm{~mm}$ in depth in average), while the damages of the roller with big spikes produced the deepest stem damages $(7.8 \mathrm{~mm}$ in average). For medium stems (volume of $0.35 \mathrm{~m}^{3}$, diameter at breast height $20-25 \mathrm{~cm}$ ), the range of differences between the maximum and minimum effective feeding time was 6-19\%, which results in 1-3\% of the efficient work time. Corresponding differences in fuel consumption during total stem processing depending on the types of feed rollers were $7-15 \%$. Finnish researchers concluded that the traditional rollers with spikes are most effective in processing and fuel consumption, but they caused also the deepest damages to the logs.

The rollers with adaptable plates in the Finnish study was the most effective for small stems and they also caused the least damage to the logs [5]. Other researchers [6] found that proper adjustments of the felling head are crucial for minimizing of the stem damages. They recommend to keep the pressure of feed rollers and delimbing knifes as low as possible to avoid deep damages. The most severe damages of logs in the Finnish studies were found at the tops of the logs, which, in spite of relatively small distribution across the stem, have negative impact on the quality of a whole log [5]. 


\section{Materials and methods}

The experimental trials were conducted in Latvia, in Vidusdaugava forestry. Overall 19 felling sites with a total area of 18.69 ha (with an average width of the felling site 0.98 ha) were harvested using the gentle feed rollers, whereas with the conventional feed rollers 15 felling sites with a total area of 20.29 ha (with an average width of the felling site 1.35 ha) were harvested. From the felling sites harvested using the gentle feed rollers, $63 \%$ were pine stands and $37 \%$ were birch stands, while in the felling sites harvested with the conventional feed rollers, the areas consisted of $57 \%$ of pine stands, $3 \%$ of spruce stands and $40 \%$ of birch stands.

The harvester model Ponsse Ergo made in the year 2008 with a Standard H7 felling head was used in the trial. The harvester felling head was fitted with the Moipu "Plate wheel feed roller" forthe trials with the gentle feed rollers, whereas in the case of the conventional feed rollers the harvester felling head was fitted with the conventional feed rollers with large spikes (about $3 \mathrm{~cm}$ ).

Within the scopeof the study the working time of the harvester was recorded for six days, dividing the work cycle of the harvester head into several elements, which characterises the parameters of the work productivity and shows the possible impact of the feed rollers on the productivity. For recording of the working time the Allegro field computer with the SDI programme for time studieswas used. When performing the time studies, the tree diameter was determined (by reading the measurement data of the harvester cutting head) as well as the tree species.

The working time elements are shown in Table 1. In this trial the most significant elements of the working time characterising the possible impact of the feed rollers are "Rollers" and "Delimbing".

Table 1

Working time elements of harvesting

\begin{tabular}{|c|c|c|}
\hline $\begin{array}{l}\text { Working time } \\
\text { category }\end{array}$ & Description & Explanation \\
\hline \multirow{7}{*}{ Informative fields } & OBS & Number of the working time recording cycle \\
\hline & $\mathrm{D}$ & Tree diameter from harvester computer, $\mathrm{mm}$ \\
\hline & Number & Number of trees gripped, pieces \\
\hline & Spruce & Species of the trees to be cut \\
\hline & Pine & Species of the trees to be cut \\
\hline & Birch & Species of the trees to be cut \\
\hline & Notes & $\begin{array}{l}\text { Different notes, including information on breaks, } \\
\text { travel, changing strip roads, etc. }\end{array}$ \\
\hline \multirow{12}{*}{$\begin{array}{c}\text { Productive } \\
\text { working time }\end{array}$} & Reach & Reaching for tree \\
\hline & Gripping & Gripping of growing tree \\
\hline & Sawing & Sawing of growing tree \\
\hline & Rollers & $\begin{array}{c}\text { Movement of feed rollers at stem bucking and } \\
\text { delimbing }\end{array}$ \\
\hline & Delimbing & Delimbing after feed rollers \\
\hline & Putting away & Putting away the material or relocating \\
\hline & Other & $\begin{array}{l}\text { Other unconventional actions/operations, } \\
\text { including stump sawing, thinking, etc. }\end{array}$ \\
\hline & Driving in & Driving into the felling site \\
\hline & Driving out & Driving out of the felling site \\
\hline & Moving & $\begin{array}{l}\text { Moving along the felling site during the felling } \\
\text { process }\end{array}$ \\
\hline & Underwood & Sawing of underwood \\
\hline & SR/Strip road & Strip road packing \\
\hline \multirow{2}{*}{$\begin{array}{l}\text { Unproductive } \\
\text { working time }\end{array}$} & Stop & Activities not related to work \\
\hline & Repairs & Machinery and equipment repairs. \\
\hline
\end{tabular}

Fuel consumption figures are obtained from the computer system report - DRF file, which characterise the average weighed fuel consumption distributed between operators. The fuel 
consumption has been calculated only for processing time. The computer system reports characterise also the average productivity figures during the trial process.

The processed roundwood meets the quality requirements "Roundwood quality requirements" set by the JSC "Latvijas valsts meži", whereas the measured amount as well as its uncertainty have been evaluated according to the StanForD standard [7]. The felling site harvesting file (PRD), work and repair follow-up file (DRF) as well as control measurement file (KTR) were used in the study. Additional measurements on the volume delivered were carried out by VMF Latvija Ltd.

\section{Results and discussion}

The fuel consumption when using the gentle feed rollers was $18.21 \cdot \mathrm{h}^{-1}( \pm 5.2)$, whereas in the case of the conventional feed rollers the consumption of fuel was $16.75 \mathrm{l} \cdot \mathrm{h}^{-1}( \pm 5.5)$. It has been mentioned in publications that the consumption of fuel varies with the tree species to be harvested and its diameter [8]. The fuel consumption distribution by the types of the feed rollers significantly affects both the mean values $\left(t_{\text {Stat }}=2.6>t_{\text {Crit }}=1.64\right)$ and the dispersion of data $\left(F=0.9>F_{\text {Crit }}=0.8\right)$. The calculations on fuel consumption are based on the harvester recording system (exclusively informative type of information), where it is possible to save the information on distribution by operators and by the type of the forestry machines used. When using the gentle feed rollers the processing time is $62 \%$, while with the conventional rollers it is $70 \%$. Thus, there is no significant difference in the processing time.

The use of the machinery during the study was analysed basing on the DRF file, Fig. 1. The DRF file presented does not allow to accurately restore the situation to its full extent since it lacks the recordings on the movement of machinery and the repairs performed.

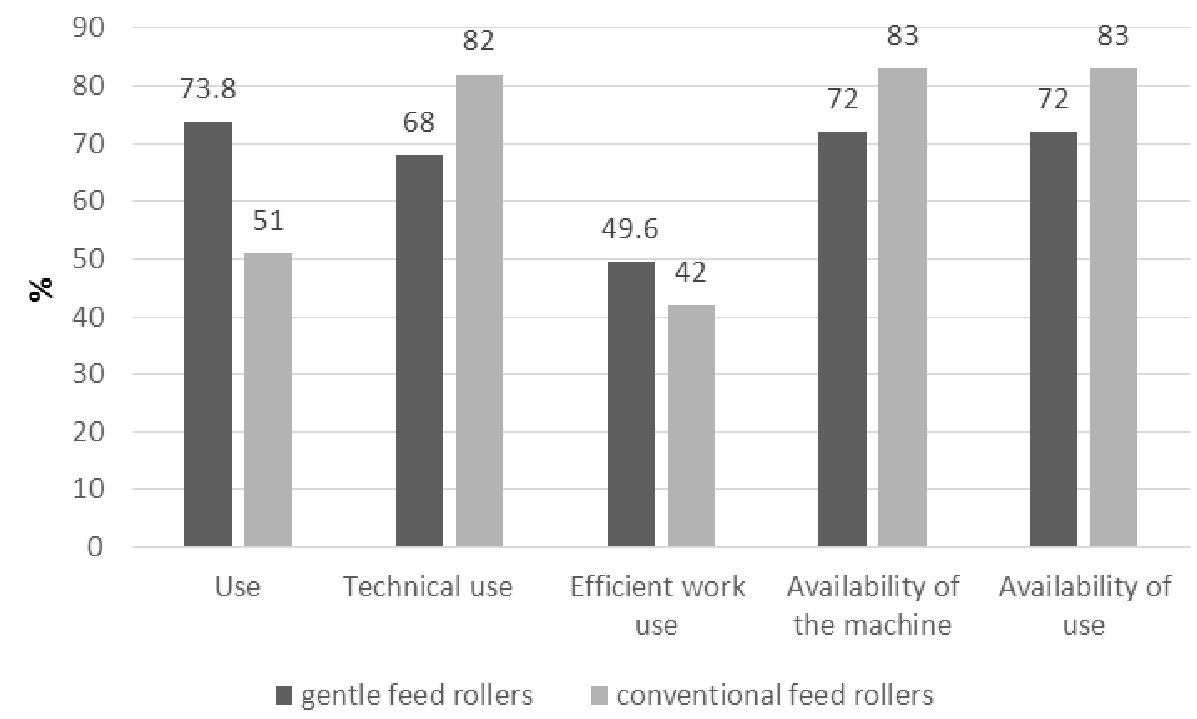

Fig. 1. Use of machinery harvesting felling sites with different feed rollers

Analysing the information obtained from DRF it is possible to substantiate the impact of feed rollers on the use of machinery. One of the parameters is "Availability of the machine" that characterises the expenditure of the efficient working time versus the efficient time plus repairs and services.

Performing the recording of the harvester working time by using a special time keeping programme it has been stated that by using the gentle feed rollers the productivity is $27 \mathrm{~m}^{3} \cdot \mathrm{h}^{-1}$, while in the case of the conventional feed rollers it is $33 \mathrm{~m}^{3} \cdot \mathrm{h}^{-1}$. The difference is statistically significant if the diameter of the trees to be cut at the height of 1.3 m exceeds $20 \mathrm{~cm}$ [5]. In harvesting smaller diameter trees no statistically significant differences were stated, although in harvesting a separate tree, using the feed rollers, the time spent was different in both cases Fig. 2. 


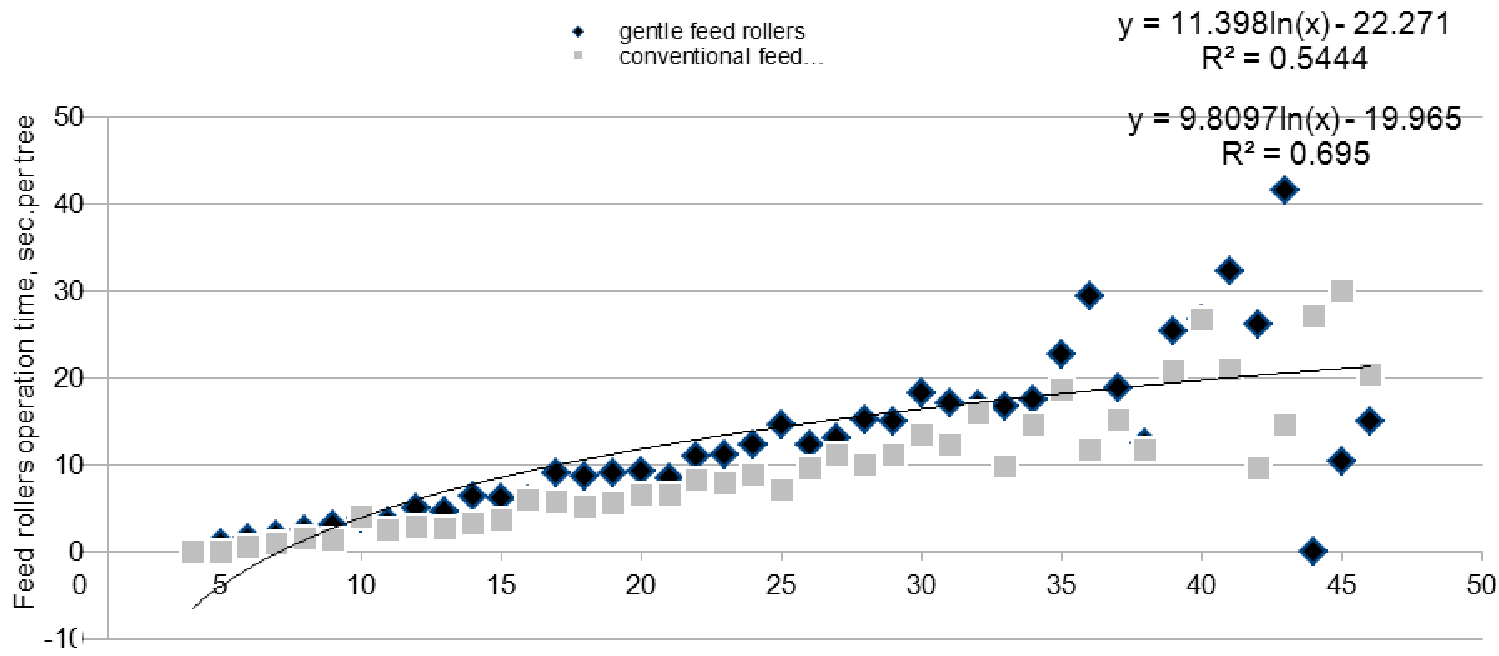

Diameter, cm

Fig. 2. Feed roller operation time per tree distributed by diameter stages

The time spent on delimbing and feed rollers, Fig. 3, in both types of feed rollers does not differ significantly $\left(F=1.32<F_{\text {crit }}=1.70, t_{\text {Stat }}=0.82<t_{\text {crit }}=1.99\right)$.

Working continuously with the gentle feed rollers, according to the work productivity parameters calculated in the study, the costs in final felling increase by $0.31 \mathrm{EUR} \cdot \mathrm{m}^{-3}$.

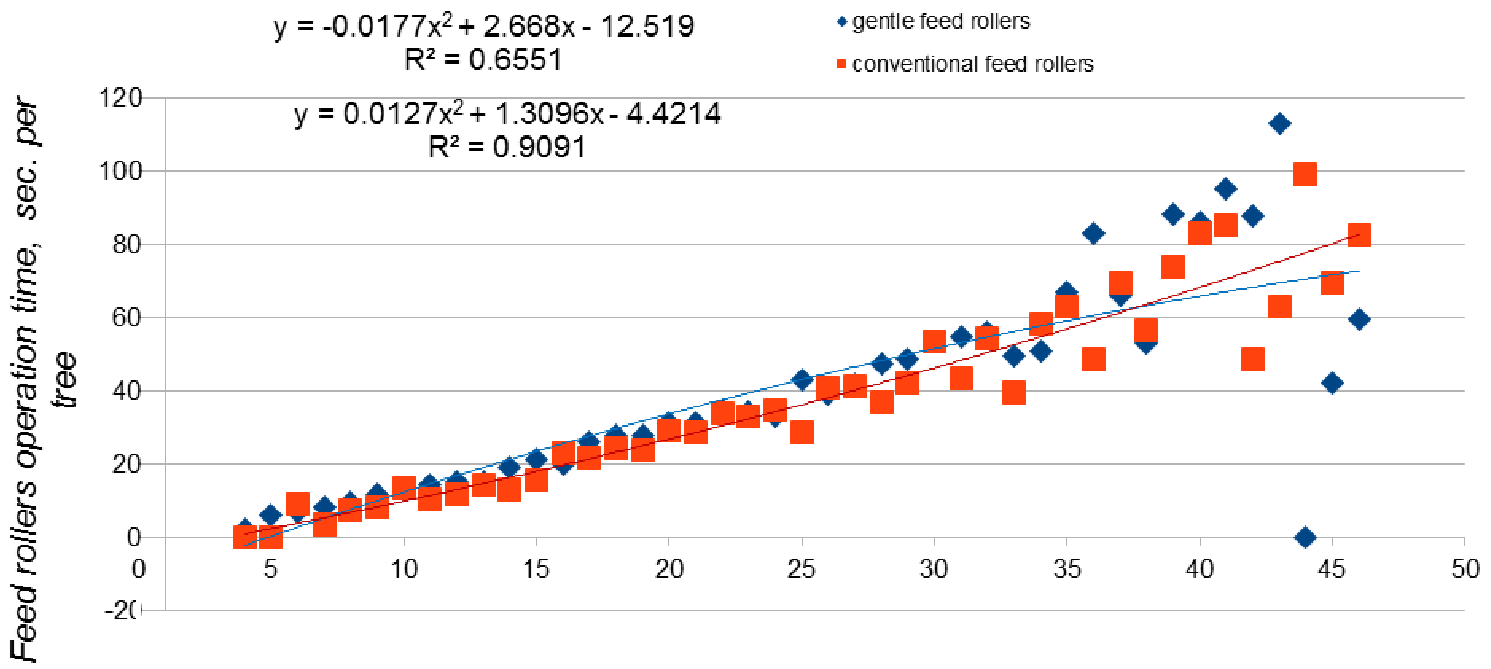

Diameter, $\mathrm{cm}$

Fig. 3. Delimbing and feed roller operation time per tree distributed by diameter levels

\section{Conclusions and recommendations}

1. Feed rollers significantly increase the productivity, when larger dimension trees are sawn $\left(D_{\text {tree diameter } 1.3 \mathrm{~m}}>20 \mathrm{~cm}\right.$ ).

2. Analysing the fuel consumption data, according to the DRF file, the fuel consumption is by $8 \%$ higher when the gentle feed rollers are used in harvesting.

3. For research purposes a special requirement is used with regard to accurate entering of the data, different from the conventionally accepted in production. Such requirement not only would allow to analyse the obtained data for the research purposes, but it would also allow the companies to keep track of the use of machinery and repairs.

4. On the basis of the harvesting recording system the fuel consumption distribution by the types of feed rollers makes a significant impact on fuel consumption. 


\section{Acknowledgements}

The study was implemented within the scope of the JSC funded research project "Research program on forest biofuel and mechanization of forest operations" (agreement No 55.9_003v_101_16_47).

\section{References}

1. Nilsson G. 1996. A feed rooler. World Intellectual Property Organization, IP Services. Publication No.WO/1996000141. International application No.PCT/SE1995/000770. [online][11.12.2016]. Avilable at:

https://patentscope.wipo.int/search/docservicepdf_pct/id00000000654240 /PAMPH/WO1996000141.pdf.

2. Mäkelä M. Vanerikoivun koneellinenhakkuu. Metsätehon katsaus. 1993. No. 2. 6 p. (In Finnish with summary in English).

3. Mäkelä M., Pannanen O. Sahatukkien valmistusja varastointivaurioiden markitys eri karsintamenetelmissä. Metsätehontiedotus 1980 No. 361.14 p. (In Finnish with summary in English).

4. Jönsson P., Hannrup B. Timber value test 2006 - timber damage and defects. Skogsforsk Resultat 2007, No 7. (In Swedish with summary in English).

5. Nuutinen Y., Väätäinen K., Asikainen A., Prinz R., Heinonen J. Operational efficiency and damage to sawlogs by feed rollers of the harvester head. 2010.Silva Fennica 44. No 1. pp. 121-139.

6. Liiri H., Asikainen A., Erikkilä A., Kaipainen H. Aalto J. Puuenergian teknologiaohjelman vuosikirja (Reducing of unwanted barking in single grip harvester cutting). In Alakangas, E. \&Holviala, N. (eds.). VTT symposium 231. Puuenergian teknologiaohjelman vuosikirja 2003, pp. 167-184. (In Finnish).

7. Räsänen T., Sorsa J. StanFord 2010 - Naming and design rules. Metsäteho Oy. 2010. 41 p.

8. Gerasimov Y., Seliverstov A., Syunev V. Industrial Round-Wood Damage and Operational Efficiency Losses Associated with the Maintenance of a Single-Grip Harvester Head Model: A Case Study in Russia. 2010. Forests 3, pp. 864-880. 